\title{
Reaching the Hard-To-Reach with Civic Education on the European Union: Insights from a German Model Project
}

\author{
Monika Oberle ${ }^{(D)}$ and Märthe-Maria Stamer * \\ Department of Political Science, University of Goettingen, \\ Platz der Goettinger Sieben 3, 37073 Goettingen, Germany; monika.oberle@sowi.uni-goettingen.de \\ * Correspondence: maerthe-maria.stamer@uni-goettingen.de
}

Received: 22 July 2020; Accepted: 23 September 2020; Published: 30 September 2020

check for updates

\begin{abstract}
So-called "hard-to-reach" learners with a lower level of formal education have been identified as a "challenge" for civic education and have been neglected with regard to civic education in the past. However, these young people do deal with political processes that relate to their everyday lives; they simply do not perceive these processes as political. The same holds true for the topic of the European Union. To date, hardly any teaching concepts and learning materials for civic education on the European Union that are specially designed for hard-to-reach youth have been available. This paper discusses the relevance, challenges, and promising approaches used to address this severe deficit in the research and practice of civic education regarding the EU. It focuses on the situation in Germany and presents the Jean Monnet project "Junge Menschen erreichbar machen mit politischer Europabildung" (JUMPER). Here, workshops with a focus on the European Union are developed-specifically tailored to the needs of the target group, carried out with pupils in the vocational transition system, and accompanied by systematic evaluation. Finally, conclusions are drawn for civic education and research regarding hard-to-reach youth.
\end{abstract}

Keywords: civic education; European Union; hard-to-reach learners; empirical research; vocational transition system; simulation game

\section{Introduction}

Nowadays, the European Union (EU) plays a vital role in the lives of people living in the EU. Ongoing European integration has led to an increasing number of decisions being made at the European level that have a direct impact on people's everyday lives. However, an alienation of people from the EU is noticeable, Brexit being the most prominent result. Wilhelm Knelangen (2015) described a "trust crisis" that could eventually become threatening for the European project. It is evident that people, especially those with a low level of formal education, are becoming disentangled from the political system and are not adequately represented on the political stage (Brinkmann 2009; Vester 2009; Sloam 2013a, 2013b; Carpenter and Taru 2016). This could threaten the political stability of a country (Detjen 2007) or of the European Union (Leruth et al. 2017). Research shows that people who directly experience the advantages of the EU tend to have a more positive attitude toward the EU compared to people who do not experience these advantages—and such a lack of positive experiences often goes along with a lower socio-economic status (Grimm et al. 2017; Hix 2009). Eurosceptical attitudes and a low level of willingness to participate often go hand in hand with a distinct lack of knowledge about the European Union (Westle 2015). These results call for a European citizenship education that specifically addresses people who are persuaded that they cannot influence European politics (Eis 2013).

This contribution focuses on civic education regarding the European Union for young hard-to-reach learners. It sheds light on the relevance and challenges of civic education on the EU, specifically 
regarding young, hard-to-reach learners and presents promising approaches to providing learning opportunities on the European Union tailored to the needs of this specific and often neglected target group. Looking at the situation in Germany, the vocational transition system is described as a suitable, but largely neglected, context for reaching so-called "hard-to-reach" youth with civic education on the EU. Finally, the Jean Monnet project "Junge Menschen erreichbar machen mit politischer Europabildung" (JUMPER) is presented, which has designed civic education measures based on existing research as well as on feedback from the target group that was involved in the development of the materials. Moreover, the design and challenges of the systematic empirical research accompanying the JUMPER workshops will be presented and discussed.

The paper is structured as follows: After this introduction, an overview is given regarding the relevance and main goals of civic education on the EU, with a special focus on the situation in Germany. Next, the relevance and specific challenges of civic education for young hard-to-reach learners, as well as promising didactic approaches, are pointed out. These outlines are followed by a presentation of the JUMPER project, highlighting the characteristics of the German vocational transition system, which serves as the project's starting point for successfully connecting hard-to-reach youth with EU education, and presenting the workshops and design of the accompanying empirical research. A final outlook will draw conclusions for civic education and research regarding hard-to-reach youth in Germany and beyond.

\section{Civic Education on the European Union in Germany}

The European Union (EU) is the most closely interconnected transnational political union worldwide, and its political decisions have significant effects on policies and on the lives of the people who live within its borders. Estimates vary, but research suggests that at least one third of the legislation passed at the federal level in Germany in recent years can be traced back to a 'European impetus' (Töller 2008, 2014; König and Mäder 2008). The politics of its member states can no longer be sufficiently understood without including the European level, but at the same time, European Union policies cannot be influenced solely via participation at the national level. Besides extending its competencies to more policy fields, the EU's deepening dynamics also mean a change in the methods of political decision-making that foresees more majority decisions in the Council of Ministers, awards more participation rights to the directly elected European Parliament, and makes it possible for the population to participate in the European legislative process, not with referendums, but with a European Citizens' Initiative. In the European multi-level system, EU-related political knowledge and competencies thus have increased in importance for the Union's citizens over the last few decades (cf., (Oberle 2015)). The ongoing European integration requires civic education on the EU in order to facilitate (young) people's understanding of these processes, their ability to judge, and their capacity to participate politically on the European level.

Because only civic education given at school has the potential to reach all young citizens, it carries a particular responsibility for European civic education that also opens up great opportunities. Kris Grimonprez (2020) argues in favor of the integration of an EU dimension into national civic education curricula. The promotion of teaching and learning about Europe and the European Union at school is furthermore on the agenda of different European actors, such as the European European Parliament Committee on Culture and Education (2016).

In Germany, the European Union was a rather neglected topic of civic education in schools and extracurricular activities in the past and not much focused upon by civic education research either. However, increasing cooperation on the European level has led to a re-examination of this topic in civic education in Germany (Rappenglück 2014, p. 392). Already in 1978, the Standing Conference of the Ministers of Education and Cultural Affairs of the Länder in the Federal Republic of Germany (Standing Conference of the Ministers of Education and Cultural Affairs of the Länder of the Federal Republic of Germany KMK) emphasized the teaching of Europe-oriented competencies as an important task of schools, including the subject civics, in order to enable pupils to live a successful life in Europe. It was 
updated in 1990 and 2008 and is currently, during the German Council presidency, 2020, again under revision, underlining the continuing significance of teaching about Europe and the European Union at school in the face of current challenges. These demands are mirrored by the school curricula of all 16 German Länder, which require dealing with the European Union in secondary level civic education at general schools (Geyr et al. 2007).

Drawing on empirical research that underlines a lack of knowledge and understanding of the European Union in the general public as well as among European and German youth, Monika Oberle and Johanna Forstmann emphasize that "a knowledgeable approach to the complex entity 'EU' cannot be acquired incidentally; instead, it requires intentional civic education" (Oberle and Forstmann 2015 , p. 82). The overarching goal of civic education remains the "development of political maturity (Mündigkeit)" (Society for Civic Education Didactics and Civic Youth and Adult Education 2004, p. 9). Based on the model of political competency by Detjen et al. (2012), they propose a catalogue of competencies with which pupils should be provided in civic education classes at school. This catalogue includes conceptual understanding of the EU; interest in the EU; a positive, EU-related internal efficacy (trust in one's own political abilities with regard to the EU) as well as fundamental trust in the EU, its institutions, and its responsiveness; and EU-related abilities to judge political questions and take political action (Oberle and Forstmann 2015, p. 82). Taking a closer look at EU-related political knowledge, the following aspects can be identified as basic knowledge about the EU: general orientational knowledge, knowledge regarding the European institutions and legislative procedures, the competences of the EU as well as modes of citizen participation (Oberle 2012).

It can be concluded that civic education on the EU is of high relevance for people living in the European Union to gain at least orientational knowledge on this unique political entity as well as a feeling of political self-efficacy and fundamental political competencies in order to enable people living in the EU to participate in the (European) political sphere. National politics can no longer be approached without a greater view on the European level. This need for a European perspective with regard to political knowledge and skills applies to all societal groups. However, some groups are disadvantaged when it comes to civic education. A target group often neglected in civic education is focused in the following chapter: hard-to-reach youth.

\section{Civic Education for Young Hard-To-Reach Learners: Relevance, Challenges, and Promising Approaches}

The international network "Networking European Citizenship Education" (NECE) defines hard-to-reach learners as "educationally and socially disadvantaged people who are often 'forgotten' by the mainstream of citizenship education or left behind in schools or other educational facilities". (Kakos et al. 2016, p. 10) This target group is viewed as a "challenge" for civic education (Detjen 2009, p. 101). Research shows a connection between a low level of formal education and a low level of political interest (Schneekloth and Albert 2019, pp. 51-52). Helmut Bremer opens up another perspective by explaining a putative low political interest with mechanisms of exclusion: individuals with a low level of formal education tend to abstain from political participation because they do not feel entitled to participate (Bremer 2012, pp. 30-33). This assumption is backed by a study from 2012 which concludes that young people from "underprivileged" milieus are in fact interested politically-their lack of interest in "institutionalized politics" stems from ignorance of political processes as well as a missing link to their everyday lives (Kohl and Calmbach 2012, pp. 21-22). However, these young people deal with political processes that relate to their everyday lives; they simply do not perceive these processes as political. Therefore, the authors conclude that these young people's political agenda is "invisible" because the scope to assess their political interest is too narrow (Kohl and Calmbach 2012, p. 23). Furthermore, Heinz-Ulrich Brinkmann points out a shifting of political representation of these groups: the low level of political participation of "underprivileged" groups leads to a lack of political representation of their concerns and needs (Brinkmann 2009, p. 69). 
Putting an emphasis on addressing young people with civic education appears to be especially worthwhile because they are in the course of becoming a "political generation": their patterns of political activity are in the process of development and their political attitudes are still subject to change (Baumert et al. 2016; Brinkmann 2009). Civic education in schools is of utmost importance as is lays the basis for the acquisition of knowledge and competencies in later years: the political knowledge one possesses as an adolescent is a decisive predictor for the level of political information one possesses in adult life. In addition, political attitudes and behavioral patterns of the adolescence tend to persevere throughout adult life (Oberle 2012).

In recent years, civic education opportunities for young hard-to-reach learners have been increasingly discussed among experts (for instance, see the following edited volumes: (Drews 2009; Widmaier and Nonnenmacher 2012)). While "classical" education opportunities usually do not seem to work well for this target group, there are some promising approaches that will be presented in the following paragraphs.

It has become evident that schools play a central role in civic education. As individuals with a lower level of formal education do not often frequent extracurricular civic education opportunities, schools of basic secondary education and vocational education are often the only place where these pupils come into contact with civic education (Brinkmann 2009, p. 90). An analysis of data of the International Civic and Citizenship Education Study (ICCS) 2016 strongly suggests the need for high quality civic education in schools-especially for pupils originating from disadvantaged households (Deimel et al. 2020). Based on their study on the invisible political agenda of young people, Wiebke Kohl and Marc Calmbach conclude that civic education needs to engage in "translation" in order to make political content accessible for hard-to-reach youth (Kohl and Seibring 2012, p. 25). Friedrun Erben, Heike Schlottau, and Klaus Waldmann edited a volume on civic education for hard-to-reach groups in 2011 in which principles for the design of civic education opportunities for this target group were identified. These are (a) subject orientation (participants are seen as individuals capable of judging and acting, not just as objects of teaching), (b) recognition and respect (participants are perceived as equal interlocutors), (c) participation (participants have the opportunity to participate), and (d) action orientation (development of real opportunities to act) (Erben et al. 2013, pp. 27-45). These principles are very similar to the didactic principles applied to civic education in general: targeting the addressees, learning from examples, controversy orientation, action-orientation, and science orientation (see, for instance, (Sander 2014)).

As a central success factor for civic education efforts targeting hard-to-reach youth, Heinz-Ulrich Brinkmann identifies closeness to everyday life and the living environment, e.g., through using social media and including locations or events frequented by youth ((Brinkmann 2009, pp. 81-82); see also, (Hradil 2012, p. 24)). Furthermore, he names "Edutainment" - teaching formats that do not put an emphasis on political learning but on learners' entertainment and on pointing out links to their everyday life-as a useful method for civic education. Conveying political content in the course of youth work may be successful (Brinkmann 2009, p. 80); this is backed by Benedikt Sturzenhecker, who also believes that civic education in youth centers is a promising approach (Sturzenhecker 2013). Arne Busse et al., summarizing successful approaches applied by the German Federal Agency for Civic Education, add computer games and participative approaches, leading to immediate feelings of success to the list of learning opportunities that have proven to be successful (Busse et al. 2012). Another promising approach is the concept of essential reduction (Elementarisierung), a procedure to reduce the complexity of political content. This concept was initially proposed by Siegfried Schiele and has since been discussed by many scholars (Detjen 2011; Kohl and Seibring 2012, p. 8; Schiele 2012).

Christian Ernst and Claudia Nickel published a piece on principles for successful civic education on the European Union, especially for hard-to-reach target groups, and identified the following factors: start out from existing competencies of the participants, create open and informal learning situations (e.g., artistic and creative approaches), choose tangible topics, show how to critically deal with information, and provide distinctive pedagogical companionship, intensive supervision, and support 
when it comes to mobility opportunities (Ernst and Nickel 2008, pp. 35-37). These can be used for orientation when designing target group specific learning opportunities on the EU.

A specific promising method for civic education with hard-to-reach groups is the use of simulation games (cf., (Petrik and Rappenglück 2017; Bursens et al. 2018; Guasti et al. 2015)). There is empirical evidence showing that political simulation games can facilitate access to politics and the European Union-even for participants who initially show only little or no interest in the matter. Playing the role of an EU politician (e.g., member of the European Parliament, Council member) and actively taking part in political negotiations and decision-making during the game can exercise an ice-breaking effect and can help overcome prejudices with regard to politics and the European Union (Oberle et al. 2018, 2020; Oberle and Leunig 2016).

There is empirical evidence that a low level of knowledge about the European Union correlates positively with eurosceptic attitudes (Westle 2015; Oberle 2012). Those experiencing the advantages of the European Union in everyday life, e.g., by participating in mobility programs, manifest more positive attitudes towards the EU as compared to those not directly experiencing these advantages (Grimm et al. 2017, p. 225; Hix 2009, pp. 59-64). Although civic education on the European Union is of special relevance for disconnected youth with a lower level of formal education, hardly any teaching concepts and learning material are available that are especially designed for hard-to-reach learners. One of the few exceptions is the publication "EUropa-Was geht für dich?", a brochure published by the German Federal Agency for Civic Education, specifically produced for this target group (Oberle and Stamer 2019). So far, how to successfully convey EU-related competencies to hard-to-reach youth remains basically unexplored. The JUMPER project specifically addresses these desiderata: both its didactic approaches and the design of its accompanying empirical study will be presented in the following section.

\section{Civic Education on the EU for Hard-To-Reach Learners: The Jean Monnet Project JUMPER}

The Jean Monnet Project "Reaching the hard-to-reach with political education on the European Union" ("Junge Menschen erreichbar machen mit politischer Europabildung" (JUMPER)) aims at facilitating civic education on the European Union that is specifically tailored to the needs of young hard-to-reach individuals. In the course of the project, a workshop focusing on the EU will be carried out ten times with a total of 150 young, hard-to-reach participants. Following the participants' feedback and the accompanying evaluation, the workshop concept will be further optimized. The final concept, including all material, will be disseminated through training seminars for multipliers (e.g., teachers, social workers) and a closing conference, which, due to the Coronavirus pandemic, has been rescheduled for spring 2021.

JUMPER's target group are 15 to 27 year-olds who are attempting to acquire the competencies required for vocational education and training or integration into the labor market. In Germany, about $5.9 \%$ of every cohort drop out of school without obtaining a school leaving certificate-this amounts to about 50,000 young people every year (Autorengruppe Bildungsberichterstattung 2018, p. 121; Deutscher Caritasverband 2019). In recent years, it is observable that the number of young people leaving school without a certificate is increasing. Many of these individuals with a low level of formal education then enroll in the vocational transition system - which therefore seems to be a promising starting point for providing civic education to hard-to-reach youth who do not often voluntarily attend extracurricular civic education measures.

\subsection{The German Vocational Transition System}

The so-called vocational transition system as a part of the German education system is located on the border between formal education at school and the labor market. This system consists of various measures, which can be divided into two strands: (a) measures of the Federal Employment Agency, characterized by close cooperation with companies and (b) school-based measures. These school-based measures lie within the area of responsibility of the 16 different $L \ddot{a} n d e r$; therefore, their exact arrangement 
varies throughout Germany. However, there are several similarities, and this second strand of measures comprises education and training measures that are inferior to a qualified vocational training measure and do not lead to a recognized qualification. The focus of these measures is rather the identification and promotion of the individual's competencies, and is aimed at integrating them into the labor market. The goal is the start of vocational training leading to a recognized qualification or taking an employment opportunity. In some cases, the belated obtainment of a school leaving certificate through participation in measures of the vocational transition system is possible (Konsortium Bildungsberichterstattung 2006, p. 79).

An overview of the different compositions of the vocational transition system in Germany was arranged by Tobias Brändle, who calls the entire vocational transition system a "storage system": the pupils are provided with an opportunity to acquire competencies they are missing for a successful integration into the labor market. The vocational transition system, therefore, can be viewed as a compensation system (Brändle 2012, p. 128) for the acquisition of knowledge, skills, and competencies that were not obtained through regular education at school.

In 2016, about 303,000 young people were newly enrolled in the vocational transition system (for a comprehensive overview of the German education system, including a location of the vocational transition system, see (European Centre for the Development of Vocational Training 2019)). About $14.5 \%$ of them took part in measures of the Federal Employment Agency (first strand of the vocational education system). About 35.8\% of the pupils are instructed in Berufsvorbereitungsjahr/einjährige Berufseinstiegsklassen (a part of the second strand of the vocational education system) and the largest faction (37.8\%) visit Berufsfachschulen, which is pre-vocational training that can be credited in later vocational training phases. The latter belongs to the second strand as well and lies within the area of responsibility of the Länder. The remaining $12 \%$ of the pupils are enrolled in other measures of the vocational transition system that will not be further discussed in this paper (Autorengruppe Bildungsberichterstattung 2018, p. 138).

Over the last few years, it has become evident that the share of pupils with foreign nationalities in the vocational transition system is rising. In 2018, 36\% of these pupils did not have German citizenship. Also notable is that $41 \%$ of the pupils with foreign citizenship enrolled in the German vocational transition system have not obtained any school leaving certificate, as opposed to $25 \%$ of pupils with German citizenship not having obtained one. Most common is a basic school leaving certificate (Hauptschulabschluss, 46.5\%), followed by a general school leaving certificate (Realschulabschluss, 26.5\%). A small number of pupils in the vocational transition system (2.8\%) scored a qualification for university entrance (Abitur) (Autorengruppe Bildungsberichterstattung 2018, p. 139).

The JUMPER project focuses on pupils attending the so-called Berufsvorbereitungsjahr/ Berufseinstiegsklassen (BVJ/BEK) (for a detailed overview, see (Brändle 2012, pp. 100, 109)); therefore, the following paragraphs provide a more detailed insight into these specific measures. The distinct characteristics of the measures BVJ/BEK can be described as follows: they are pre-vocational measures aimed at providing pupils with competencies and skills allowing them to start vocational training or take up employment. Pupils are usually educated in two areas of the labor market in order to gain orientation with regard to their occupational choices and opportunities. The time spent in these measures is not credited to reduce the time spent in vocational training programs. It is, however, usually possible to obtain a basic school leaving certificate (Hauptschulabschluss) at the end of the measure, which lasts one or two school years, depending on the Länder. Due to the federalized structure of the vocational transition system in Germany, these two measures cannot be separated accurately and they carry different denominations throughout Germany. In the following, the term Berufsvorbereitungsjahr/Berufseinstiegsklasse (BVJ/BEK) is used to describe those measures that share the characteristics outlined above. Brändle (2012) assembled a detailed itemization of the different measures.

To be eligible for participation in the BVJ/BEK, pupils usually have to prove completion of mandatory full-time education. The BVJ/BEK usually lasts one school year, and it is possible to 
hereby obtain a school leaving certificate. The aim of this measure is passage into vocational training, and some Länder also aim for direct integration into the labor market without prior vocational training or specific qualifications (Brändle 2012, pp. 98-99). Apart from occupational orientation, participants usually receive socio-pedagogical support to address individual deficits during the BVJ/BEK (for instance, see Niedersächsisches Kultusministerium 2011, which provides details on the federal state of Lower-Saxony).

Anja Besand closely examined the situation of civic education in vocational schools and concludes that it is a marginalized subject. Through interviews with teachers, she identifies a variety of challenges that are associated with the teaching of civic education in vocational schools, namely a lack of recognition regarding the importance and relevance of the subject (and, consequently, out-of-field teaching), the pupils' (assumed) lack of interest in politics, and the heterogeneity of the student body, as well as the myriad of different pathways at vocational schools. Pupils enrolled in the BVJ/BEK are identified as a particularly challenging group when it comes to civic education teaching (Besand 2014, pp. 121-50).

About 108,500 individuals started the measure BVJ/BEK in 2016 (Autorengruppe Bildungsberichterstattung 2018, p. 138). Taking a closer look at this group based on a study carried out by the Bundesinstitut für Berufsbildung (BIBB) in 2011 shows that one quarter of the pupils taking part in BVJ/BEK had either not graduated from school or had graduated from a special needs school. Fifty-eight percent of the pupils had completed secondary education with a basic school leaving certificate. A second finding from this study is the low formal education level of the pupils' parents. While $23 \%$ of the parents did not complete vocational education and training and reached a general school leaving certificate (Realschulabschluss), at maximum, 32\% of the parents have reached a basic school leaving certificate (Hauptschulabschluss) and completed vocational education and training (Beicht and Eberhard 2013, pp. 15-16). Forty percent of the pupils in the BVJ/BEK had a migration background (Beicht and Eberhard 2013, pp. 15-16). While the gender ratio seems well-balanced in the 2011 study, newer data from 2018 show a larger share of male pupils in the vocational transition system: 65.5\% male, 34.5\% female (Autorengruppe Bildungsberichterstattung 2018, p. 315; calculations by the authors).

\subsection{The Workshops: Didactic Concept and Evaluation}

During the JUMPER project, a total of 10 workshops, with about 150 pupils overall of the BVJ/BEK, will be conducted by two trainers of the University of Goettingen. They will each last two full school days (usually from 8 a.m. to 1 p.m.). The advantage of carrying out the workshops in a school setting is that it gives a certain level of continuity among the participants. Additionally, for the evaluation of the workshops, it is vital that a majority of the participants participates throughout the two days of the workshop. As some of the pupils work in the afternoons or have other obligations-or their attention span is limited-the duration of the workshop is aligned with the duration of a regular school day. Because classes in the vocational transition system are usually small (about 8-10 pupils), two or more classes will be combined for the workshops.

Most of the participants will take a closer look at the European Union for the first time during the workshop. During the development of the workshop elements, it was assumed that the young people only have little knowledge about the European Union and that they are unaware of the EU's relevance for their everyday lives. Research shows that text-based approaches are not suitable for young, hard-to-reach youth. Therefore, JUMPER focuses on activity-oriented, playful approaches, because they appear most promising for the work with young, hard-to-reach youth: the two-day workshops are designed as "special events". The JUMPER project is aimed at rousing the participants' curiosity regarding the European Union. Throughout the workshop, the pupils will be familiarized with basic knowledge on the EU (e.g., history, institutions, functioning of the EU) and they will learn where and how to find information on the EU and what opportunities they have to make their voices heard on the European level. 
The workshops, scheduled for autumn 2020, will begin with interactive icebreakers, allowing the participants to get to know the workshop facilitators as well as each other, if they have not met before. In the next step, links between the European Union and the pupils' everyday lives are highlighted. The participants have the opportunity to reveal previous knowledge about the EU and add topics they are particularly interested in to the workshop. Thereafter, the history of the European Union is briefly presented in an interactive format. A focus of the workshop's first day is the functioning of the EU, with a special view to the institutions, in order to prepare the pupils for the second day of the workshop. At the end of the day, the participants examine decisions regarding plastic pollution on the European level. The central element of the JUMPER workshops is a simulation game that takes place on day 2. It was specifically designed for the target group. The Berlin-based company Planpolitik (www.planpolitik.de) was contracted to develop this simulation game. The participants take on the roles of members of the European Parliament from different countries and different political backgrounds who have to decide on future rules regarding packaging material made from plastic in the EU. The simulation game's topic was chosen because of its tangibility: Plastic packaging of fruit and vegetables is a topic that young people can relate to, the different lines of conflict around this topic are easily traceable, and the plastic pollution is not as emotionally charged as other topics, such as, e.g., migration, which helps create a fact-based discussion. For this reason, pupils have little difficulty representing an opinion that is not their own during the discussion.

At the end of every workshop, a person who is involved in activities on the European level is scheduled to visit. These guests are either members of the European Parliament (MEP), local politicians with a focus on EU politics, or young activists who are involved in pan-European youth groups, such as the Young European Federalists, for instance. The workshop participants prepare the visit, questions are collected throughout the workshops, and the pupils can present the results of their simulation game to their guest in order to receive an idea of how this issue could be decided in real life at the European level. If members of the European Parliament visit the workshop, pupils have a chance to profit from first-hand experience from the European Parliament. However, due to the European Parliament's schedule, MEPs are not always available. The workshop organizers prepare the guests for their visit, making sure they are able to make a connection between the workshop participants and the European Union.

All workshops are to be evaluated. The evaluation design includes a survey at three measuring points: participants are asked to fill out a questionnaire before the workshop (pre), after the workshop (post), and a few weeks after the workshop (follow-up). The questionnaire is aimed at assessing the effects of the workshop (short-term and in a longer perspective) as well as eliciting feedback on the methods and materials from the participants. In addition, EU-related orientations of the participants (knowledge, attitudes, motivations, and readiness to act) as well as success factors for political education on the EU for this specific target group are investigated. The evaluation follows a mixed-methods design: the questionnaire survey is complemented by guideline-based interviews with selected participants $(n=20)$ at all three measuring points in order to gain a deeper understanding of the factors mentioned above.

The evaluation's setup caters to the specific needs of the target group: the questionnaires are kept as short as possible with a strictly limited number of open-ended questions. Furthermore, the questionnaires are filled out online with the support of the two workshop facilitators. This approach has two central advantages: Every participant can fill out the questionnaire at their own pace, anonymously, and, in case of questions, the workshop facilitators can offer assistance. In addition, the participants, who are often not used to and are intrigued by larger amounts of reading material, enjoy filling out the questionnaire on the computer. The reduced reading requirement, with one question per page, helps the participants to complete the questionnaire successfully. 


\section{Outlook}

Research on civic education as well as on civic education practice have not taken hard-to-reach groups into account (enough) in the past. This is despite the fact that individuals who can be classified as "hard-to-reach" for civic education make up a considerable part of society. Approaches to successful civic education on the European Union specifically for hard-to-reach youth are widely unexplored. Practical methods and ready-to-use materials for such an endeavor hardly exist. However, national and European politics are entangled to such a large extent nowadays that individuals require knowledge and competencies related to the EU in order to reach the ultimate goals of civic education: political maturity, ability to judge, and ability to act. The JUMPER project is aimed at closing this gap in civic education research and practice through developing and evaluating methods and material specifically designed for civic education on the EU for hard-to-reach youth. Choosing the German vocational transition system as a starting point seems promising as it is a formal educational context attended by the target group. These youth usually do not participate in extracurricular activities dealing with civic education; therefore, it is necessary to meet them where they are. Usually, the vocational transition system provides few learning opportunities with regard to civic education: this subject is marginalized in lower secondary and vocational schools and is often taught by teachers without subject-specific training.

Targeting this specific group in the rather formalized setting of BVJ/BEK also provides the opportunity for systematic evaluation of the intervention and optimization of the workshop concept and materials. Providing ready-to-use workshop concepts and materials with proven target group adequacy to teachers can help alleviate the reservations against teaching civic education to hard-to-reach youth. Evaluating the effectiveness of civic education interventions and collecting participants' feedback is important for the further development of such measures. Finding a practicable evaluation design to collect data on civic education measures for hard-to-reach youth is a central goal of the JUMPER project. Combined with the evaluation's results, the workshop concept focusing on Europe/the European Union as well as the material can be transferred to improve civic education to hard-to-reach youth in other countries. Moreover, the evaluation results identifying good practices with regard to the design of civic education measures specifically tailored to the needs of hard-to-reach youth could be the basis for the development of civic education measures focusing on different topics, in Germany and beyond.

Funding: The JUMPER project is co-financed by the European Commission, 611653-EPP-1-2019-1-DE-EPPJMOPROJECT, Grant decision number 2019-1632/001-001. We acknowledge support by the Open Access Publication Funds of the University of Goettingen.

Ethics Statement: The pupils participate voluntarily in the workshop and the accompanying evaluation. All data is anonymized, and written consent from participants and their parents was sought before the intervention. The intervention and research were permitted by the respective State Boards of Education (Landesschulbehörden).

Conflicts of Interest: The authors declare no conflict of interest.

\section{References}

Autorengruppe Bildungsberichterstattung. 2018. Bildung in Deutschland 2018. Ein indikatorengestützter Bericht mit einer Analyse zu Wirkungen und Erträgen von Bildung. Bielefeld: wbv Media.

Baumert, Jürgen, Michael Becker, Kai Cortina, Olaf Köller Michaela Kropf, and Kai Maaz. 2016. Die Entwicklung des politischen Interesses und des Selbstkonzepts der politischen Kompetenz vom Jugend- bis in das Erwachsenenalter. In Kritische Bildungsforschung: Standortbestimmungen und Gegenstandsfelder. Edited by Anne Schippling, Cathleen Grunert and Nicolle Pfaff. Opladen: Verlag Barbara Budrich, pp. 323-52.

Beicht, Ursula, and Verena Eberhard. 2013. Ergebnisse empirischer Analysen zum Übergangssystem auf Basis der BIBB-Übergangsstudie 2011. Die Deutsche Schule 105: 10-27.

Besand, Anja. 2014. Monitor Politische Bildung an beruflichen Schulen. Probleme und Perspektiven. Schwalbach/Ts: Wochenschau Verlag.

Brändle, Tobias. 2012. Das Übergangssystem: Irrweg oder Erfolgsgeschichte? Opladen: Budrich UniPress. 
Bremer, Helmut. 2012. "Bildungsferne" und politische Bildung. Zur Reproduktion sozialer Ungleichheit durch das politische Feld. In Unter erschwerten Bedingungen: Politische Bildung mit bildungsfernen Zielgruppen. Edited by Benedikt Widmaier and Frank Nonnenmacher. Schwalbach/Ts: Wochenschau Verlag, pp. $27-41$.

Brinkmann, Heinz Ulrich. 2009. "Politikferne Zielgruppen" in der politischen Bildungsarbeit. In Politisch Nicht mehr Erreichbar? Politikverdrossenheit und Soziale Milieus. Edited by Albert Drews. Loccum: Evangelische Akademie Loccum, pp. 69-99.

Bursens, Peter, Vincent Donche, David Gijbels, and Pieter Spooren, eds. 2018. Simulations of Decision-Making as Active Learning Tools. Cham: Springer.

Busse, Arne, Wiebke Kohl, and Saskia Mey. 2012. Politische Bildung mit bildungs- und politikfernen Zielgruppen. Ansätze der Bundeszentrale für politische Bildung. In Unter erschwerten Bedingungen: Politische Bildung mit bildungsfernen Zielgruppen. Edited by Benedikt Widmaier and Frank Nonnenmacher. Schwalbach/Ts: Wochenschau Verlag, pp. 89-102.

Carpenter, Mick, and Marti Taru. 2016. Asking the questions the right way round? Young people's political participation in Europa: Reflections on the MYPLACE study. In Beyond Us Versus Them: Citizenship Education with Hard to Reach Learners in Europe. Edited by Michalis Kakos, Christoph Müller-Hofstede and Alistair Ross. Bonn: Bundeszentrale für Politische Bildung, pp. 283-303.

Deimel, Daniel, Bryony Hoskins, and Hermann J. Abs. 2020. How do schools affect inequalities in political participation: Compensation of social disadvantage or provision of differential access? Educational Psychology 40: 146-66. [CrossRef]

Detjen, Joachim, Peter Massing, Dagmar Richter, and Georg Weißeno. 2012. Politikkompetenz. Ein Modell. Wiesbaden: Springer VS.

Detjen, Joachim. 2007. Politische Bildung für bildungsferne Milieus. APuZ 32-33: 3-8.

Detjen, Joachim. 2009. Bildungsferne Milieus als Herausforderung der politischen Bildung. In Politisch nicht mehr Erreichbar? Politikverdrossenheit und soziale Milieus. Edited by Albert Drews. Loccum: Evangelische Akademie Loccum, pp. 101-8.

Detjen, Joachim. 2011. Elementarisierung. Grundsätzliche Überlegungen zur Brauchbarkeit eines didaktischen Schlüsselbegriffs für die politische Bildung. In Bürger auf Abwegen? Politikdistanz und politische Bildung. Edited by Siegfried Frech and Ingo Juchler. Schwalbach/Ts: Wochenschau Verlag, pp. 207-40.

Deutscher Caritasverband. 2019. Studie Bildungschancen vor Ort. Available online: https://www.caritas.de/ bildungschancen (accessed on 21 July 2020).

Drews, Albert. 2009. Politisch nicht mehr erreichbar? Politikverdrossenheit und soziale Milieus. Loccum: Evangelische Akademie Loccum.

Eis, Andreas. 2013. The EU as a Topic of Citizenship Education: The Democratic Deficit and the Loss of Trust in the European Project as New Challenges. Paper presented at the Workshop at the NECE Conference, The Hague, The Netherlands, November 14-16.

Erben, Friedrun, Heike Schlottau, and Klaus Waldmann. 2013. Gestaltungsprinzipien. In "Wir haben was zu sagen!" Politische Bildung mit sozial benachteiligten Jugendlichen. Subjektorientierung-Anerkennung-Partizipation. Edited by Friedrun Erben, Heike Schlottau and Klaus Waldmann. Schwalbach/Ts: Wochenschau Verlag, pp. 25-46.

Ernst, Christian, and Claudia Nickel. 2008. Europavermittlung mit “bildungsfernen Zielgruppen”. In Europa vermitteln. Handbuch zur europabezogenen Jugendbildung. Edited by Hans-Georg Wicke. Bonn: Jugend für Europa, Deutsche Agentur für das EU-Programm Jugend in Aktion, pp. 32-38.

European Centre for the Development of Vocational Training. 2019. Vocational Education and Training in Europe. Germany. Available online: https://www.cedefop.europa.eu/en/tools/vet-in-europe/systems/ germany (accessed on 22 July 2020).

European Parliament Committee on Culture and Education. 2016. Report on Learning EU at School. Available online: https://www.europarl.europa.eu/doceo/document/A-8-2016-0021_EN.pdf (accessed on 21 July 2020).

Geyr, Maja von, Lilly Hornung, Friederieke Noack, Jaroslav Sonka, and Eckhart D. Stratenschulte. 2007. Die Europäische Dimension in den Lehrplänen der Deutschen Bundesländer. Berlin: EAB.

Grimm, Robert, Gary Pollock, and Mark Ellision. 2017. Eurosceptic Youth. In The Routledge Handbook of Euroscepticism, 1st ed. Edited by Benjamin Leruth, Nicholas Startin and Simon Usherwood. Florence: Taylor and Francis, pp. 215-30. 
Grimonprez, Kris. 2020. The European Union and Education for Democratic Citizenship: Legal Foundations for EU Learning at School. Baden-Baden: Nomos. [CrossRef]

Guasti, Petra, Wolfang Muno, and Arne Niemann. 2015. Introduction-EU simulations as a multi-dimensional resource: From teaching and learning tool to research instrument. European Political Science 14: 205-17. [CrossRef]

Hix, Simon. 2009. What's Wrong with the European Union and How to Fix it; Cambridge: Polity Press.

Hradil, Stefan. 2012. Soziale Milieus in der politischen Bildung. In "Unsichtbares" Politikprogramm? Themenwelten und politisches Interesse von "bildungsfernen" Jugendlichen. Edited by Wiebke Kohl and Anne Seibring. Bonn: Bundeszentrale für politische Bildung, pp. 15-25.

Kakos, Michalis, Christoph Müller-Hofstede, and Alistair Ross. 2016. Introduction. In Beyond Us Versus Them: Citizenship Education with Hard to Reach Learners in Europe. Edited by Michalis Kakos, Christoph Müller-Hofstede and Alistair Ross. Bonn: Bundeszentrale für politische Bildung, pp. 9-32.

Standing Conference of the Ministers of Education and Cultural Affairs of the Länder of the Federal Republic of Germany (KMK). 2008. Europabildung in der Schule. Available online: https://www.kmk.org/fileadmin/ Dateien/veroeffentlichungen_beschluesse/1978/1978_06_08_Europabildung.pdf (accessed on 21 July 2020).

Knelangen, Wilhelm. 2015. Die Europäische Union und die Bürgerinnen und Bürger: Stimmungsschwankungen oder handfeste Vertrauenskrise? In Die Europäische Union Erfolgreich Vermitteln: Perspektiven der Politischen EU-Bildung Heute. Edited by Monika Oberle. Wiesbaden: Springer VS, pp. 13-25.

Kohl, Wiebke, and Marc Calmbach. 2012. Unsichtbares Politikprogramm? Lebenswelten und politisches Interesse von “bildungsfernen" Jugendlichen. In Unter erschwerten Bedingungen: Politische Bildung mit Bildungsfernen Zielgruppen. Edited by Benedikt Widmaier and Frank Nonnenmacher. Schwalbach/Ts: Wochenschau Verlag, pp. 17-26.

Kohl, Wiebke, and Anne Seibring. 2012. "Unsichtbares" Politikprogramm? Themenwelten und politisches Interesse von "bildungsfernen" Jugendlichen. Bonn: Bundeszentrale für politische Bildung.

König, Thomas, and Lars Mäder. 2008. Das Regieren jenseits des Nationalstaates und der Mythos einer 80-Prozent-Europäisierung in Deutschland. Politische Vierteljahresschrift 49: 438-463. [CrossRef]

Konsortium Bildungsberichterstattung. 2006. Bildung in Deutschland: Ein indikatorengestützter Bericht mit einer Analyse zu Bildung und Migration. Bielefeld: Bertelsmann.

Leruth, Benjamin, Nicholas Startin, and Simon Usherwood, eds. 2017. The Routledge Handbook of Euroscepticism, 1st ed. Florence: Taylor and Francis.

Niedersächsisches Kultusministerium. 2011. Materialien. Handlungskompetenz im Berufsvorbereitungsjahr (BVJ). Available online: https://www.nibis.de/nli1/bbs/archiv/rahmenrichtlinien/mbvj2011.pdf (accessed on 21 July 2020).

Oberle, Monika, and Johanna Forstmann. 2015. Förderung EU-bezogener Kompetenzen bei Schüler/innen-Zum Einfluss des politischen Fachunterrichts. In Die Europäische Union Erfolgreich Vermitteln: Perspektiven der Politischen EU-Bildung heute. Edited by Monika Oberle. Wiesbaden: Springer VS, pp. 81-98.

Oberle, Monika, and Johanna Leunig. 2016. Planspiele im Politikunterricht-Nur etwas für politisch interessierte Jugendliche? In Herausforderung Migration: Perspektiven der Politischen Bildung. Edited by Thomas Goll, Monika Oberle and Stefan Rappenglück. Schwalbach/Ts: Wochenschau Verlag, pp. 125-33.

Oberle, Monika, and Märthe-Maria Stamer. 2019. Was geht für dich? Das Heft über die Europäische Union. Bonn: Bundeszentrale für politische Bildung.

Oberle, Monika, Sven Ivens, and Johanna Leunig. 2018. Effects of EU simulation games on secondary school pupils' political motivations, attitudes and knowledge-Results of an intervention study. In Simulations of Decision-Making in Political Science. Edited by Peter Bursens, David Gijbels, Vincent Donche and Pieter Spooren. Heidelberg: Springer, pp. 145-64.

Oberle, Monika, Johanna Leunig, and Sven Ivens. 2020. What do students learn from political simulation games? A mixed-method approach exploring the relation between conceptual and attitudinal changes. European Political Science 19: 367-86. [CrossRef]

Oberle, Monika. 2012. Pupils' political knowledge regarding the European Union. Citizenship, Social and Economics Education 11: 89-104. [CrossRef]

Oberle, Monika. 2015. Learning about the European Union at school-Theoretical considerations and empirical evidence. Australian \& New Zealand Journal of European Studies 7: 26-44. 
Petrik, Andreas, and Stefan Rappenglück, eds. 2017. Handbuch Planspiele in der politischen Bildung. Schwalbach/Ts: Wochenschau Verlag.

Rappenglück, Stefan. 2014. Europabezogenes Lernen. In Handbuch Politische Bildung, 4th ed. Edited by Wolfgang Sander. Bonn: Bundeszentrale für Politische Bildung, pp. 392-400.

Sander, Wolfgang, ed. 2014. Handbuch Politische Bildung, 4th ed. Bonn: Bundeszentrale für Politische Bildung.

Schiele, Siegfried. 2012. Elementarisierung als neue Strategie für politische Bildung. In Unter Erschwerten Bedingungen: Politische Bildung mit Bildungsfernen Zielgruppen. Edited by Benedikt Widmaier and Frank Nonnenmacher. Schwalbach/Ts: Wochenschau Verlag, pp. 77-88.

Schneekloth, Ulrich, and Mathias Albert. 2019. Jugend und Politik: Demokratieverständnis und politisches Interesse im Spannungsfeld von Vielfalt, Toleranz und Populismus. In Jugend 2019: Eine Generation Meldet sich zu Wort, 1st ed. Edited by Shell Holding GmBH. Weinheim: Beltz, pp. 47-101.

Sloam, James. 2013a. The 'Outraged Young': How Young Europeans are Reshaping the Political Landscape. Political Insight 4: 4-7. [CrossRef]

Sloam, James. 2013b. 'Voice and Equality': Young People's Politics in the European Union. West European Politics 36: 836-858. [CrossRef]

Society for Civic Education Didactics and Civic Youth and Adult Education. 2004. Nationale Bildungsstandards für den Fachunterricht in der Politischen Bildung an Schulen: Ein Entwurf, 2nd ed. Schwalbach/Ts: Wochenschau Verlag.

Sturzenhecker, Benedikt. 2013. Die Stimme erheben und mitbestimmen. Politische Bildung in der Offenen Kinder- und Jugendarbeit. In "Wir Haben Was zu Sagen!": Politische Bildung mit Sozial Benachteiligten Jugendlichen; Subjektorientierung-Anerkennung-Partizipation. Edited by Friedrun Erben, Heike Schlottau and Klaus Waldmann. Schwalbach/Ts: Wochenschau Verlag, pp. 213-23.

Töller, Annette Elisabeth. 2008. Mythen und Methoden. Zur Messung der Europäisierung der Gesetzgebung des Deutschen Bundestages jenseits des 80-Prozent-Mythos. Zeitschrift für Parlamentsfragen 39: 3-17. [CrossRef]

Töller, Annette Elisabeth. 2014. Europäisierung der deutschen Gesetzgebung. Wissenschaftliches Kurzgutachten. Available online: https:/ub-deposit.fernuni-hagen.de/servlets/MCRFileNodeServlet/mir_derivate_00000959/ T\%C3\%B6ller_Kurzgutachten_Europ\%C3\%A4isierung_Gesetzgebung_2014.pdf (accessed on 21 July 2020).

Vester, Michael. 2009. Soziale Milieus und die Schieflagen politischer Partizipation. In Politisch Nicht mehr Erreichbar? Politikverdrossenheit und Soziale Milieus. Edited by Albert Drews. Loccum: Evangelische Akademie Loccum, pp. 9-56.

Westle, Bettina. 2015. Wissen um die Direktwahl des Europäischen Parlaments—Eine Frage des Alters? Deutsche im westeuropäischen Vergleich. In Die Europäische Union Erfolgreich Vermitteln: Perspektiven der Politischen EU-Bildung Heute. Edited by Monika Oberle. Wiesbaden: Springer VS, pp. 39-63.

Widmaier, Benedikt, and Frank Nonnenmacher, eds. 2012. Unter Erschwerten Bedingungen: Politische Bildung mit Bildungsfernen Zielgruppen. Schwalbach/Ts: Wochenschau Verlag. 